\title{
PALEOECOLOGICAL SIGNIFICANCE OF PALYNOMORPHS FROM PALEONTOLOGICALY-DATED MAASTRICHTIAN-DANIAN DEPOSITS, BIR ABU MINQAR AREA, SOUTH WESTERN DESERT, EGYPT
}

Maher I. El-Soughier

Geology Department, Faculty of Science, Aswan University, Aswan 81528, Egypt

\begin{abstract}
This study is carried out on the Dakhla Formation deposits at the Bir Abu Minqar section, South Western Desert, Egypt. Maastrichtian/Danian palynofloras have been recovered from the micropaleontology (foraminifera-nannoplankton)- and macropaleontology (bivalvia-ammonites)- dated deposits of the upper Dakhla Formation. Pteridophytic and liverworts spores, pollen of gymanosperms and angiosperms as well as dinoflagellate cysts have been identified. Angiosperm pollen includes typical members of the Late Cretaceous Palmae Province such as Spinizonocolpites echinatus. Presence of palm pollen and hygrophylic pteridophytic spores suggest a prevalence of humid tropical conditions during the deposition of the studied section, with Nypa palm mangroves thriving in the intertidal swamps that bordered the Late Cretaceous shallow sea at the area of the Abu Minqar.
\end{abstract}

Keywords: Maastrichtian-Danian, paleoecology, palynomorphs, South Western Desert, Egypt.

\section{INTRODUCTION}

The Bir Abu Minqar section ( $26^{\circ} 31^{`} 05^{\prime \prime} \mathrm{N}, 2^{\circ} 39^{`} 43^{\prime \prime} \mathrm{E}$ ), approximately $260 \mathrm{~km}$ northwest of Mut Dakhla at the bend of the Dakhla-Farafra road, is located in the north of the Abu Minqar Village in the Western Desert (Fig. 1). The deposits of this section belong to the Dakhla Formation (introduced by Said, 1961) of the latest Cretaceous-earliest Paleogene (Maastrichtian-Danian) age.

Fig. 1. Sketched map showing the location of the Birr Abu Mina section (modified from Tantaway et al., 2001).

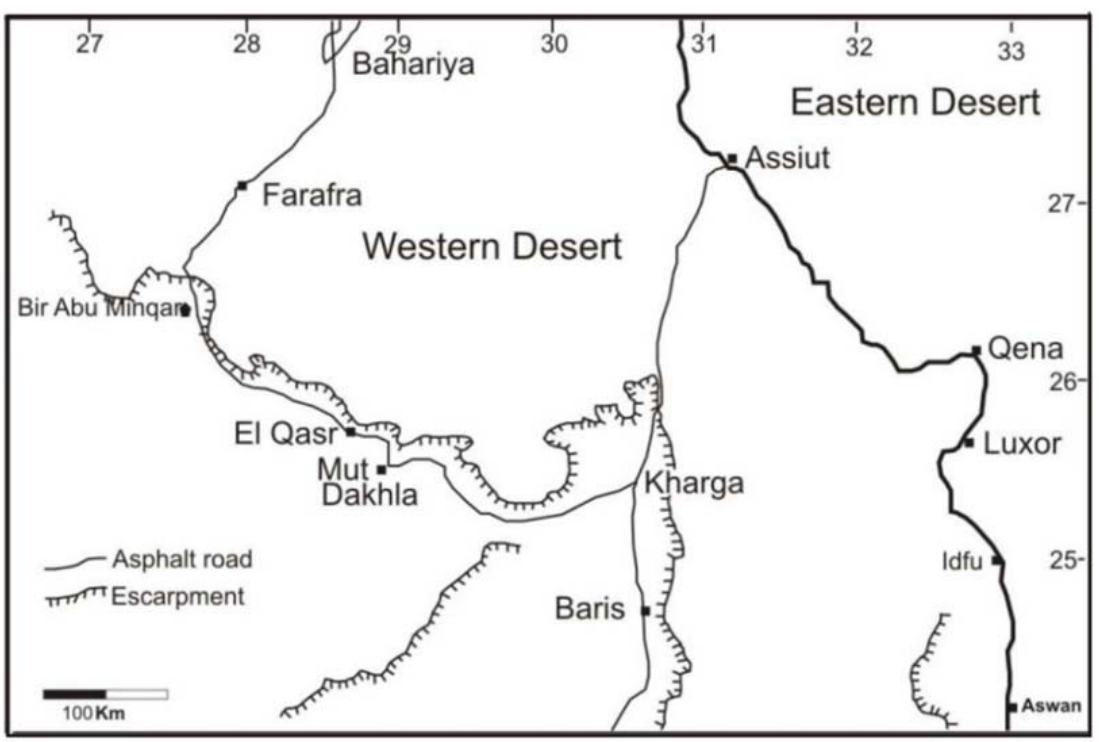

\section{Geological background}

The Dakhla formation is of special interest because of the rhythmic deposition of shales and glauconite-rich facies. Numerous studies have been made on the geology, biostratigraphy and sedimentology of the deposits exposed in the Dakhla Basin (e.g. Said, 1961, 1962; Hermina et al., 1961; Abbas and Habib, 1969; Issawi, 1972; El- Dawoody and Zidan, 1976; Omara et al., 1976, 1977; Barthel 


\section{El-Soughier, M. I.}

and Hermann-Degen, 1981; Mansour et al., 1982; Faris, 1984; Hendriks et al., 1987; Luger and Schrank, 1987; Luger, 1988; Hermina, 1990; Kassab and Zakhera, 1995; Kassab et al., 1995; Tantawy et al., 2001). The deposits of the Bir Abu Minqar section are composed primarily of silty shale and thick calcareous sandstone beds that are rich in Exogyra overwegi (Bivalvia) and sphenodiscid ammonites (Barthel and Herrmann-Degen, 1981). Exogyra overwegi zone is approximately equivalent to the lower part of the planktonic foraminiferal zone CF7 and the lower part of the calcareous nannofossil zone CC25 (Tantawy et al., 2001). According to Tantway et al. (2001, fig. 9), the Bir Abu Minqar section has the deposits of the Lower and lower Upper Maastrichtian, and after a hiatus the lower part of Danian. This is equivalent respectively to the planktonic foraminiferal zones CF7, CF6, and P1d (or P2), or the calcareous nannofossil zones CC 25a, CC25b, and NP4, spanning from about 70 to 69 Ma and 61-62Ma. This study is the first palynological study for the Bir Abu Minqar deposits. A future comprehensive set of samples from the studied deposits will be analyzed in a high-resolution work to infer possible biostratigraphic significance of palynomorphs. Since the current study is devoted essentially to contribute some paleoecologic significance of palynomorphs.

\section{MATERIAL AND METHODS}

In this study, 15 surface samples from Bir Abu Minqar area were studied. The deposits of the Dakhla Formation at the Bir Abu Minqar section are composed primarily of silty shale and thick calcareous sandstone beds (Fig. 2). 7 samples are productive only and yielded palynomorphs. They were prepared using the standard processing techniques (e.g. Wood et al., 1996). The semi-quantitative analysis of the recovered palynomorphs is presented in figure 2. Photomicrographs of selected spores, pollen and dinoflagellate cyst specimens have been complied as Plate 1 . The sample material and organic residues are housed in the collections of the Nanjing Institute of Geology and Palaeontology, Chinese Academy of Sciences, China. The microscope slides, primary data and figured material are housed in the collections of the Geology Department, Faculty of Science, Aswan Univ., and Aswan, Egypt.

\section{RESULTS}

Sparse and fairly preserved palynomorph associations (Plate 1) are recovered. Pollen and spores are the dominated groups (Fig. 2). The most common spore and pollen genera are Deltoidspora spp., Triplanisporites sp., Inaperturopollenites spp., Spheripollenites sp., Araucariacites australlis, and Spinizocolpites sp. The known ranges of selected palynomorphs recovered from the Bir Abu Minqar section (Fig. 2) suggest a Maastrichtian age for the palynologically productive parts of the studied section. Angiosperm pollen of stratigraphic significance include typical member of the Late Cretaceous Palmae Province (Herngreen et al., 1996) such as Spinizocolpites sp. (samples AM-4, AM-6 and AM-10, Fig. 2). In the North African region, several important Campanian-Maastrichtrian angiosperm taxa were recorded such as Spinizocolpites (Schrank, 1984; El Beialy, 1995; Mahmoud, 2003; Mahmoud and Schrank, 2007). The triporite pollen is the most biostratigraphically significant genus recognized in this study. It has been reported from the Egyptian part of the Northern Gondwana Realm from the upper Cenomanian up to the Maastrichtrian (Schrank, 1994; Schrank and Ibrahim, 1995; Ibrahim, 1996; Schrank and Mahmoud, 1998; Mahmoud and Schrank, 2007; Deaf et al., 2014).

Dinoflagellate cysts are poor; they are identified only from sample AM-14. The most common dinoflagellate cysts are Palaeoperidinium cretaceum, Subtilisphaera senegalensis, Subtilisphaera sp., and Oligosphaeridium sp. The dinoflagellate cyst taxa in this interval have relatively long range extending from the Early to the Late Cretaceous. Subtilisphaera senegalensis was originally described from the Aptian of Senegal (Jain and Millepied, 1973). It was later recoded from the Aptian-Albian of Egypt (e.g. Schank and Ibrahim, 1995; Ibrahim, 1996; Deaf et al., 2014). Similarly, it was frequently identified from Aptian rocks in Northwest Africa, specifically in Morocco and Libya (e.g.: Below, 1984; Thusu and Van der Eem, 1985). However, this speies was found to range up to the Maastrichtian in the far eastern part of the Tethys (Shaozhi and Geoffrey, 1988). Palaeoperidinium cretaceum was also reported in Egypt to range from the Aptian to the Maastrichtian (e.g.: El Beialy, 1995; Deaf et al., 2016). 


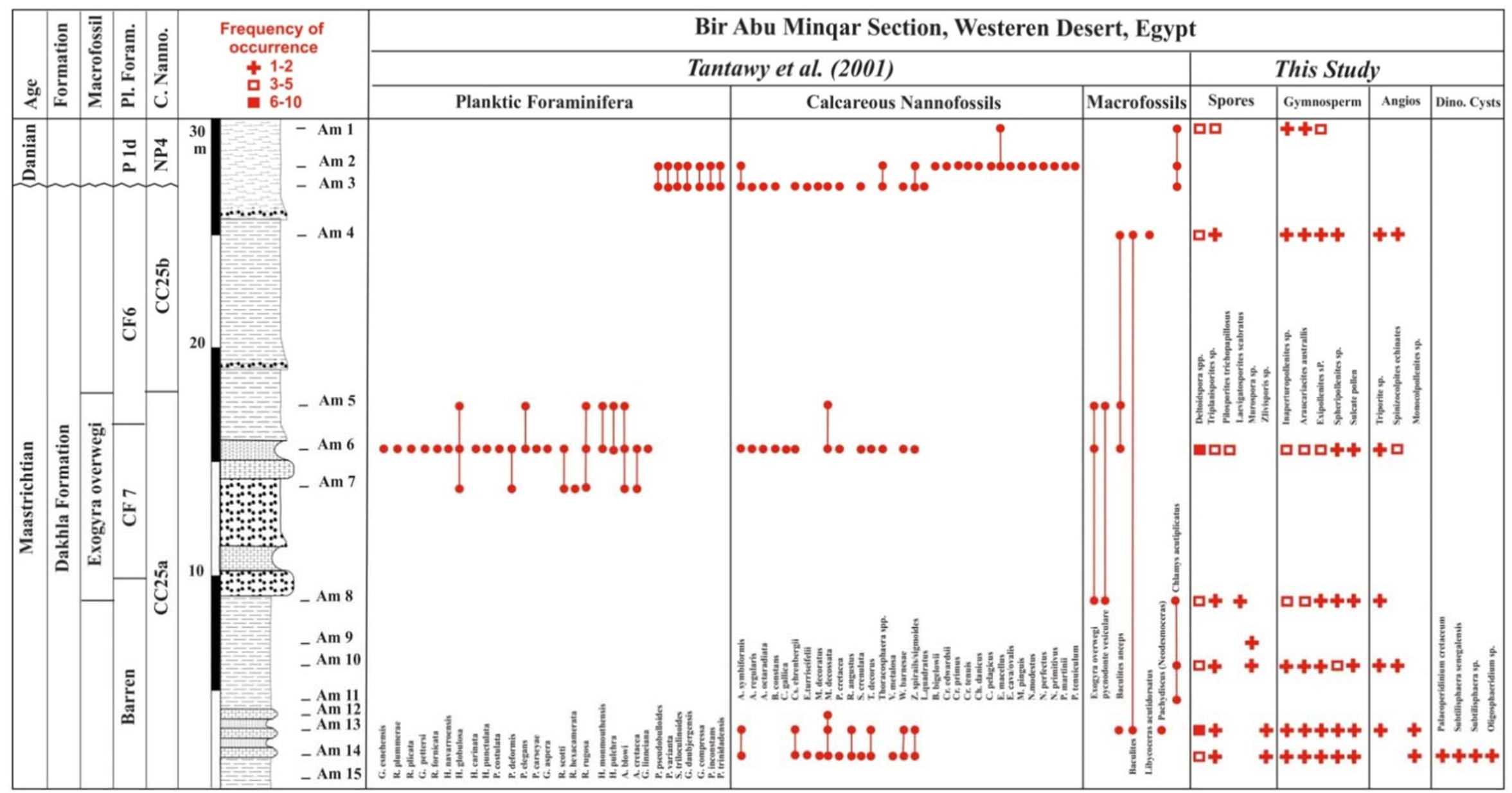

Fig. 2: Micropaleontology and macropaleontology age calibration of the Bir Abu Minqar section (after Tantway et al., 2011) and The semi-quantitative analysis of the recovered palynomorphs in the current study. (+ 1- 2 Rare, $\boldsymbol{\square}$ 3-5 present, $\mathbf{\square}$ 6-10 common). 


\section{PALEOECOLOGICAL IMPLICATIONS}

Paleoecologic and palaeoclimatic considerations in this section are based essentially on composition of palynoflora (Fig. 2). In most of the studied samples, the present to common abundances of the hygrophilous palynomorphs (mainly fern spores) such as Deltoidospra and rare to present abundances of the (liverworts spores) Zlivisporis probably reflect the local pteridophyte vegetation and wetlands (Schrank and Mahmoud, 1998; Mahmoud and Schrank, 2007; Deaf et al., 2014, 2020). In addition, the rare to present abundances of the araucariacean pollen (Araucariacites australlis) reflect conifer vegetation on relatively dry hinterlands (Schrank and Mahmoud, 1998; Mahmoud and Moawad, 2002; Deaf et al., 2020).

Pollen of palms is an important element of the terrestrial palynoflora of the Bir Abu Minqar section. Palms may have been abundant in tropical humid lowlands of the coastal plain where they were associated with pteridophytes and other plants that inhabited lowland sites (e.g. Schrank and Mahmoud, 1998; Deaf et al., 2014, 2020). The presence of a Nypa mangrove belt is indicated by the rare to present abundances of the Spinizonocolpites (Fig. 2). In Egypt, this is the southernmost occurrence of this widespread mangrove type, which was previously recorded from northern and central Egypt (e.g. Schrank, 1987; Schrank and Ibrahim, 1995; Mahmoud and Schrank, 2007; ElSoughier, 2011).

It is important to mention that the Late Cretaceous period was characterized by a relatively warmer climate and high eustatic sea levels (Stanley, 1999) in contrast to the early Paleocene that was relatively cooler and drier (Gould, 1993). Nypa vegetation reached its peak during the Eocene when the climate shifted towards warmer conditions (Corner, 1966). Nypa mangrove was recorded to dominate the swamp settings in West Africa during the Eocene (Sowunmi, 1986). By the end of the Eocene, the climate shifted towards cool conditions, which became unfavorable for Nypa to survive and eventually vanished. Based on the data mentioned above, the occurrence of the Nypa mangrove pollen (Spinizonocolpites) suggests the development of warm humid swamp conditions during deposition of the studied Upper Cretaceous rocks. The mostly rare abundances of the hot dry indictor pollen grains Exesipollenites sp. and Inaperturopollenites spp. also support the interpretation of the prevalence of regional humid conditions at the study area (e.g. Doyle et al., 1982; Schrank and Mahmoud, 1998; Deaf et al., 2020).

In the lower part of the section, the rare abundances of the peridinioid dinoflagellate cysts Palaeoperidinium and Subtilisphaera reflect marginal marine environment (e.g. Mahmoud and Schrank, 2007; Deaf et al., 2014, 2020). This interpretation is consistent with conclusion derived from sedimentological, mineralogical, and micro- and macrofossil evidences from the Dakhla Basin including our studied area (Fig. 2). During the Maastrichtian-early Paleocene, a shallow sea inundated the Western Desert of Egypt and reached as far south as of the Dakhla Basin (Tantawy et al., 2001). Tantawy et al. (Op. Cit) suggested that regional climate shifted towards more humid conditions during the latest Maastrichtian-earliest Paleocene as is evidenced from the increased kaolinite deposition. Thus, it is suggested that the Nypa palm mangroves recoded herein most probably grew in the intertidal swamps that bordered this shallow sea at the area of Abu Minqar.

\section{CONCLUSION}

1. 18 species of Maastrichtian-Danian palynofloras were recovered from the Bir Abu Minqar section. The productive samples favor a Maastrichtian age as is established by macro- and microfossils.

2. The most common palynofloras are Deltoidspora spp., Triplanisporites sp., Inaperturopollenites spp., Spheripollenites sp., Araucariacites australlis, and Spinizocolpites.

3. Presence of palm pollen along with the hygrophylic pteridophytic spores related to water ferns and hepatics suggests a prevalence of humid tropical conditions during the deposition of the upper Dakhla Formation deposits at the Bir Abu Minqar area. Nypa palm mangroves probably grew in the intertidal swamps bordering the Late Cretaceous (Maastrichtian) shallow sea at the area of Abu Minqar. 


\section{Plate}
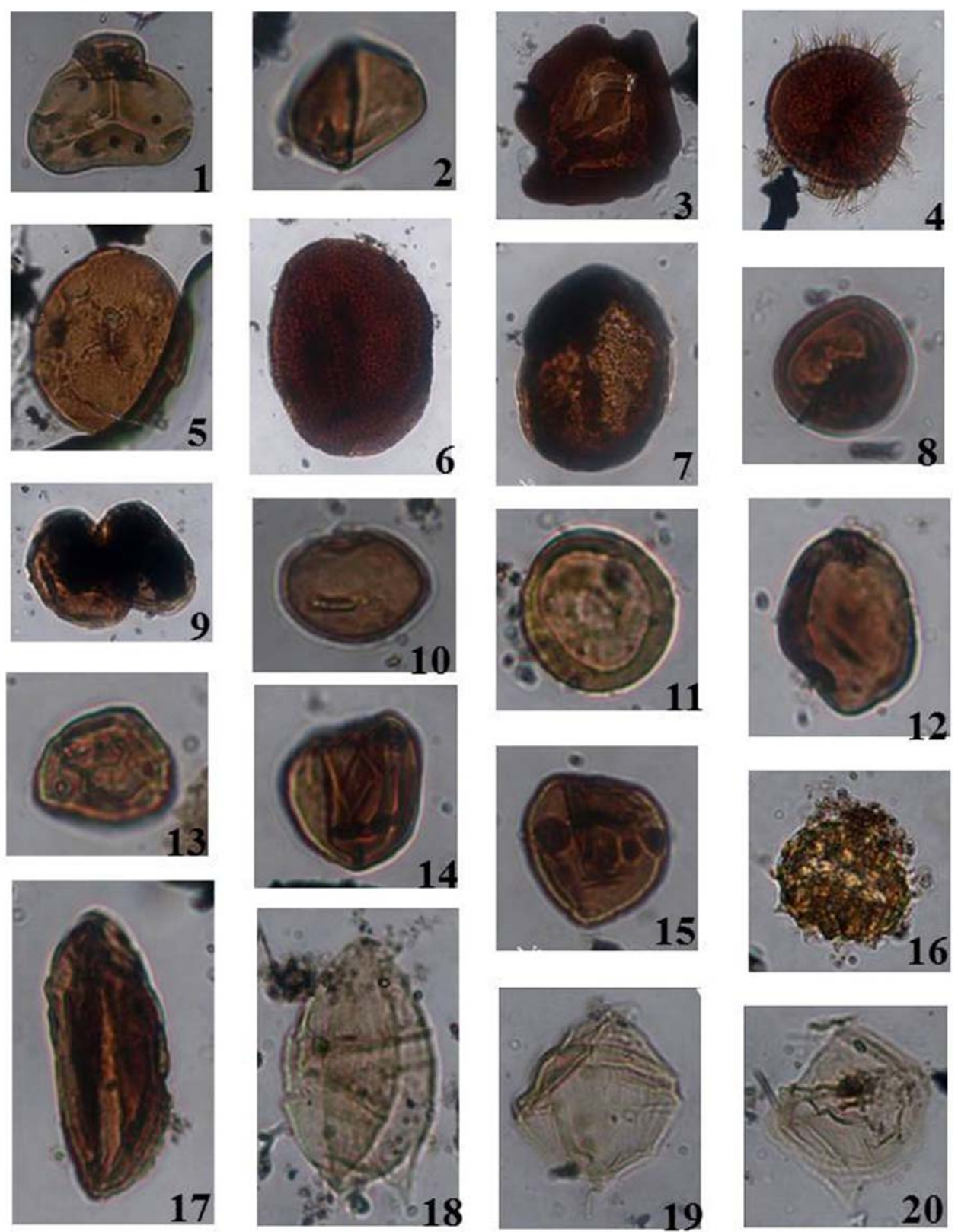

Magnifications are $600 \times(1-11,17-20) ; 1000 \times(12-16)$

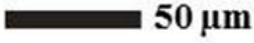

Plate. 1: Spores (1-4), pollen (5-17) and dinoflagellate cysts (18-20) of Danian-Maastrichtian Bir Abu Minqar section (AM). Magnifications are 600X (1-11, 17-20); 1000X (12-16).

1. Deltoidspora sp., AM- 4, Diameter $62 \mu \mathrm{m}$. 2. Triplanisporites sp., AM-1, Diameter $56 \mu \mathrm{m} .3$. Murospora sp., AM-10, Diameter $82 \mu \mathrm{m}$. 4. Pilosisporites trichopapillosus (Thiergart) Delcourt\& Sprumont, 1955, AM-6, Diameter $68 \mu \mathrm{m}$. 5, 8, 11, 15. Inaperturopollenites sp., AM- 8, Diameter 40 $\mu \mathrm{m}$, AM-13, Diameter $88 \mu \mathrm{m}$. 6. Punctatosporites scabratus (Couper) Norris, 1965, AM- 8,

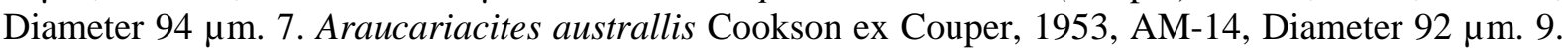
Spheripollenites sp., AM-14, Diameter $32 \mu \mathrm{m} .10$. Exipollenites sp., AM-13, Diameter $34 \mu \mathrm{m} .12,14$. Proteacidites sp., AM- 13, Diameter 32-44 $\mu \mathrm{m}$. 16. Spinizocolpite echinatus Muller, 1968, AM-10, Diameter $36 \mu \mathrm{m}$. 17. Monocolpopollenites sp., AM-13, Diameter $90 \mu \mathrm{m}$. 13. Zlivisporis sp. sensu Mahmoud and Schrank, 2007, 18. Subtilisphaera sp., AM-14, Length $90 \mu \mathrm{m}$. 19. Subtilisphaera senegalensis Jain \& Millepied, 1973, AM-14, Length $58 \mu \mathrm{m}$. 20. Palaeoperidinium cretaceum Poccok, 1962, AM-14, Length $67 \mu \mathrm{m}$, breadth $68 \mu \mathrm{m}$. 


\section{ACKNOWLEDGEMENTS}

My great thanks to the Nanjing Institute of Geology and Palaeontology, Chinese Academy of Sciences, China. I'm greatly indebted to Prof. Dr. Abdel Aziz Tantawy for providing samples of the Bir Abu Minqar. Thanks are also due to Assoc. Prof. Amr Deaf at Assiut University, Egypt for his constructive comments and critical reading of the manuscript. I would like also to thank the reviewers for their critical review and valuable comments.

\section{REFERENCES}

Abbas, H. L. and Habib, M. M. (1969): Stratigraphy of west Mawhoob area, Southwestern Desert, Egypt. Bull. Inst. Desert d'Egypt 19 (2), 48-108.

Barthel, K.W. and Hermann-Degen, W. (1981): Late Cretaceous and Early Stratigraphy in the Great Sand Sea and its SE margins (Farafra and Dakhla Oases), SW Desert, Egypt. Mitt. Bayer. Staats. Palaönt. Hist. Geol. 21, 141-182.

Below, R. (1984): Aptian to Cenomanian dinoflagellate cysts from the Mazagan plateau, northwest Africa (sites 545 and 547, Deep Sea Drilling Project Leg 79). Init. Rep. Deep Sea Drill. Proj. 79, 621-649.

Corner, E. J. H. (1966): Natural History of Palms. Weidenfeld and Nicolson, London, 393 pp.

Deaf, A. S., Harding, I. C. and Marshall, J. E. A. (2014): Cretaceous (Albian-?early Santonian) palynology and stratigraphy of the Abu Tunis 1x borehole, northern Western Desert, Egypt. Palynology, 38: 51-77.

Deaf, A. S., Harding, I. C. and Marshall, J. E. A. (2016): Early Cretaceous palynostratigraphy of the Abu Tunis $1 \mathrm{x}$ borehole, northern Western Desert, Egypt, with emphasis on the possible palaeoclimatic effect upon the range of Dicheiropollis etruscus in North Africa. Palynology, 40: 25-53.

Deaf, A. S., Harding, I. C. and Marshall, J. E. A. (2020): Cretaceous (Hauterivian-Cenomanian) palaeoceanographic conditions in southeastern Tethys (Matruh Basin, Egypt): Implications for the Cretaceous climate of northeastern Gondwana. Cret. Res., 106, 104229.

Doyle, J. A., Jardiné, S., Doerenkamp, A. (1982): Afropollis, a new genus of early angiosperm pollen, with notes on the Cretaceous palynostratigraphy and paleoenvironments of northern Gondwana. Bull. Centr. Recher. Explor. Produc. Elf Aquitaine 6, 39-117.

El Beialy, S. Y. (1985): Late Tertiary Dinocysts from the Nile Delta and Comparison with a Western Mediterranean Site. Ph. D. thesis. University of Sheffield, Sheffield (UK), 411pp.

El-Dawoody, A. S. and Zidan, M. A. (1976): Micro and nannopaleontology of the Upper CretaceousPaleocene succession in west Mawhoob area, Dakhla Oasis, Egypt. Rev. Esp. Micropaleont. 8, 401-428.

Faris, M. (1984): The Cretaceous-Tertiary boundary in central Egypt (Duwi region, Nile Valley, Kharga and Dakhla oases). Abh. Neu. Jahrb. Geol. Palaont. 7, 385-392.

Gould, S. J. (1993): The Book of Life. Norton and Company, New York, 256 pp.

Hendriks, F., Luger, P., Biwitz, J. and Kallenbach, H. (1987): Evolution of the depositional environments of SE Egypt during the Cretaceous and lower Tertiary. Berl. Geowiss. Abh. A 75, 49-82.

Hermina, M. (1990): The surroundings of Kharga, Dakhla and Farafra oases. In: Said, R. (Ed.), The geology of Egypt. Balkema, Rotterdam/Brookfield, 259-292.

Hermina, M. H., Ghobrial, M.G. and Issawi, B. (1961): The geology of the Dakhla Oasis area. Geological Survey and Mineral Research Department, Cairo, 33 pp.

Issawi, B., (1972). Review of Upper Cretaceous-Lower Tertiary stratigraphy in central and southern Egypt. Bull. Amer. Assoc. Petrol. Geol. 56, 1448-1463.

Herngreen, G. F. W., Kedves, M., Rovnina, L. V. and Smirnova, S. E. (1996): Chapter 29C, Cretaceous palynofloral provinces: a review. In: Jansonius, J. and McGregor, D.C. (ed.), Palynology: priciples and applications; Amer. Assoc. Stratig. Palynol. Found. 3, 1157-118

Ibrahim, M. I. A. (1996): Aptian-Turonian palynology of the Ghazalat-1 well (GTX-1), Qattara Depression, Egypt. Rev. Palaeobot. Palynol. 94, 137-168.

Issawi, B. (1972): Review of Upper Cretaceous-Lower Tertiary stratigraphy in central and southern Egypt. Bull. Amer. Assoc. Petrol. Geol. 56, 1448-1463.

Kassab, A and Zakhira, M. S. (1995): Maastrichtian and Paleocene bivalves from the Western Desert, Egypt. N. Jahrb. Geol. Paläont. Abh. 196, 327-346. 


\section{Paleoecological significance of Palynomorphs}

Kassab, A., Kenawy, A. and Zakhira, M. (1995): Biostratigraphy of some Upper Cretaceous-lower Tertiary outcrops from the Egyptian Western Desert. N. Jahrb. Geol. Paläont. Abh. 196, 309-326.

Luger, P. (1988): Maastrichtian to Paleocene facies evolution and Cretaceous/Tertiary boundary in middle and southern Egypt. Rev. Esp. Micropaleont., Numero Extraordinario, 83-90.

Luger, P. and Schrank, E. (1987): Mesozoic to Paleogene transitions in middle and southern Egypt summary of paleontological evidence. In: Matheis, G., Schandelmeir, H. (Eds.) Current Research in African Earth Sciences. Balkema, Rotterdam, 199-202

Mansour, H. H., Issawi, B. and Askalany, M. M. (1982): Contribution to the geology of West Dakhla Oasis area, Western Desert, Egypt. Ann. Geol. Surv. Egypt 12, 255-281.

Mahmoud, M. S. and Moawad, A. M. M. (2002): Cretaceous palynology of the Sanhur-1X borehole, northwestern Egypt. Rev. Esp. Micropaleont. 34 (2), 129-143.

Mahmoud, M.S. and Schrank, E. (2007): Late Cretaceous spores, pollen and dinoflagellates from two boreholes (Nuqra-1 and 3) in the Aswan area, southeast Egypt. Rev. Paléobiol. Genéve 26 (2), 593613.

Shaozhi, m. and Geoffrey, N. (1988): Late Cretaceous-early Tertiary dinoflagellates and acritarchs from the Kashi area, Tarim Basin, Xinjiang Province, China. Life Sci. Contrib., 150.

Omara, S., Philobbos, E. R and Mansour, H. H. (1976): Contribution to the geology of the Dakhla Oasis area, Western Desert, Egypt. Bull. Fac. Sci, Assiut Univ. 5, 319-339.

Omara, S., Philobbos, E. R. and Mansour, H. H. (1977). Contribution to the geology of the phosphorites of the Dakhla Oasis area, Western Desert, Egypt. First Conference on Min. Metallur. Techn., Assiut Univ., 21-35.

Said, R. (1961): Tectonic framework of Egypt and its influence on distribution of foraminifera. Bull. Amer. Assoc. Petrol. Geol., 45, 198-218.

Said, R. (1962): The geology of Egypt. Elsevier, Amsterdam, 377 pp.

Schrank, E. (1987): Paleozoic and Mesozoic palynomorphs from northeast Africa (Egypt and Sudan) with special references to Late Cretaceous pollen and dinoflagellates. Berl. Geowiss. Abh. A 75, 1, 249-310.

Schrank, E. (1994): Non marine Cretaceous palynology of northern Kordofan, Sudan, with notes on fossils Salviniales (water ferns). Geol. Rund., 83, 773-786.

Schrank, E. (2001): Paleoecological aspects of Afropollis/Elaterates peaks (Albian-Cenomanian pollen) in the Cretaceous of northern Sudan and Egypt. IX International Palynological Conference, Houston (1996), Amer. Assoc. Stratigr. Palynol. Found., 201-210

Schrank, E. and Ibrahim, M. I. A. (1995): Cretaceous (Aptian-Maastrichtian) palynology of foraminifera-dated wells (KRM-1, AG-18) in northwestern Egypt. Berliner Geowiss. Abh. 177, 144.

Schrank, E. and Mahmoud, M. S. (1998): Palynology (pollen, spores and dinoflagellates) and Cretaceous stratigraphy of the Dakhla Oasis, central Egypt. J. Afr. Earth Sci. 26, 167-193.

Sowunmi, M.A. (1986): Change of vegetation with time. In: Lawson, G.W. (Ed.), Plant Ecology in West Africa. John Wiley and Sons, Chichester, 273-307.

Stanley, S. M. (1999): Earth System History. W. H. Freeman and Company, New York, 315.

Tantawy, A. A., Keller, G., Addatte, T., Stinnesbeck, W., Kassab, A. and Schulte, P. (2001): Maastrichtian to Paleocene depositional environment of the Dakhla Formation, Western Desert, Egypt: Sedimentology, mineralogy, and integrated micro-and macrofossil biostratigraphies. Cret. Res. 22, 795-827.

Thusu, B. and Van der Eem, G. L. A. (1985): Early Cretaceous (Neocomian-Cenomanian) palynomorphs. J. Micropalaeont., 4, 131-150.

Wood, G.D., Miller, M.A. (1997): Stratigraphic, paleoecologic and petroleum genera 631 significance of Chlorophyta (Chlorococcalean Algae) in the Cretaceous of Western Africa 632 and South America. Afr. Geosci. Rev. 4 (3/4), 499-510.

Wood, D. G., Gabriel, A. M., Lawson, J. C. (1996). Palynological techniques - processing and microscopy. In: Jansonius, J., McGregor, D.C. (Eds.), Palynology: Principles and Applications, 1. Amr. Assoc. Stratigr. Palynol. Found., 29-50. 
El-Soughier, M. I.

\section{Appendix}

List of species

\section{Spores and pollen grains}

Araucariacites australlis Cookson ex Couper, 1953

Deltoidspora spp.

Exesipollenites sp.

Inaperturopollenites spp.

Punctatosporites scabratus (Couper) Norris, 1965

Monocolpopollenites sp.

Murospora sp.

Pilosisporites trichopapillosus (Thiergart) Delcourt \& Sprumont, 1955

Triplanisporites sp.

Proteacidites sp.

Spinizocolpites echinatus Muller, 1968

Zlivisporis sp.

\section{Dinoflagellate cysts}

Palaeoperidinium cretaceum Poccok, 1962

Oligosphaeridium sp.

Subtilisphaera senegalensis Jain \& Millepied, 1973

Subtilisphaera sp. 
Paleoecological significance of Palynomorphs

الأثار البيئية للحفريات النباتية من رواسب المسترختي -الدانيان المعرفة بالحفريات-منطقة ابو منقار - جنوب الصحراء الغريبة -مصر

ماهر ابراهيم الصغير

الخلاصة

قسم الجيولوجيا- كلية العلوم - جامعة اسوان

أجريت هذه الدراسة على رواسب تكوين الداخلة في منطقة بئر أبو منقار ، جنوب الصحراء الغربية ، مصر. نم

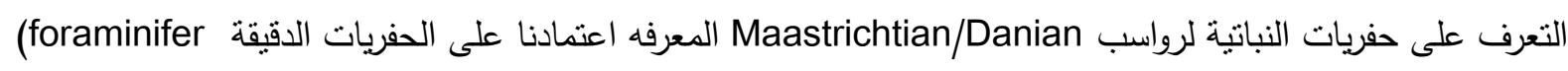
nannoplankton) التعرف على الأيواغ والنباتات المحبة للماء، وحبوب اللقاح والسوطيات. يشمل لقاح Angiosperm على فئى لكرين

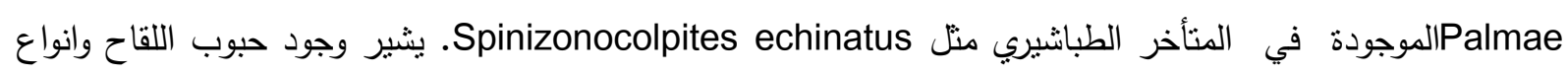

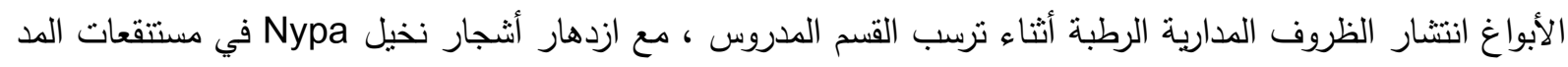

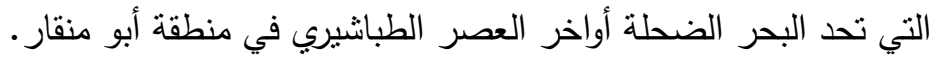

